Jurnal Keperawatan Silampari

Volume 5, Nomor 1, Desember 2021

e-ISSN: 2581-1975

p-ISSN: 2597-7482

DOI: https://doi.org/10.31539/jks.v5i1.3057

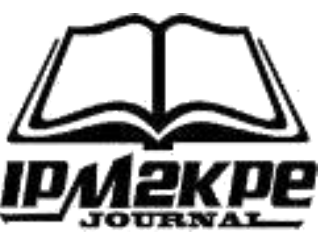

\title{
KEPATUHAN PRAKTIK PROTOKOL KESEHATAN COVID-19 PADA PENYINTAS
}

\author{
Marylin Susanti Junias ${ }^{1}$, Sarci M. Toy ${ }^{2}$ \\ Universitas Nusa Cendana ${ }^{1,2}$ \\ marylin.junias@staf.undana.ac.id ${ }^{1}$
}

\begin{abstract}
ABSTRAK
Penelitian ini bertujuan untuk menggambarkan kepatuhan praktik protokol kesehatan COVID-19 dan sumber informasi tentang pencegahan COVID-19 pada penyintas di Kota Kupang. Jenis penelitian yang digunakan dalam penelitian ini adalah deskriptif kuantitatif. Hasil penelitian menunjukkan mayoritas penyintas COVID-19 patuh dalam menggunakan alat pelindung diri berupa masker (96\%), melakukan cuci tangan pakai sabun/hand sanitizer (84\%), menerapkan jaga jarak (88\%), dan menghindari kerumunan (88\%). Simpulan, Sumber informasi tentang pencegahan COVID-19 pada penyintas COVID-19 di Kota Kupang berasal dari televisi, radio, dan internet/sosial media (Whatsapp/Facebook/ Instagram/Youtube). Paparan informasi mengenai cara pencegahan dan pengalaman mengalami COVID-19 menjadikan penyintas COVID-19 menjadi lebih patuh dalam menerapkan praktik protokol kesehatan di masyarakat.
\end{abstract}

Kata Kunci: COVID-19, Penyintas, Protokol Kesehatan

\section{ABSTRACT}

This study aims to describe the adherence to the COVID-19 health protocol practice and sources of information about the prevention of COVID-19 among survivors in Kupang City. The type of research used in this research is descriptive quantitative. The results showed that the majority of COVID-19 survivors were obedient in using personal protective equipment in the form of masks (96\%), washing hands with soap/hand sanitizer (84\%), practicing social distancing (88\%), and avoiding crowds (88\%). In conclusion, the sources of information regarding the prevention of COVID-19 for COVID-19 survivors in Kupang City come from television, radio, and internet/social media (Whatsapp/Facebook/Instagram/Youtube). Exposure to information on how to prevent and experience COVID-19 makes COVID-19 survivors more obedient in implementing health protocol practices in the community.

Keywords: COVID-19, Survivors, Health Protocol

\section{PENDAHULUAN}

Corona Viruses (CoV) adalah keluarga besar virus yang menyebabkan penyakit mulai dari flu biasa hingga penyakit yang lebih parah seperti MERS-CoV dan SARSCoV. Gejala corona virus disease 2019 (COVID-19) ini, sangat mirip dengan gejala flu disertai dengan pneumonia (radang paru), yang mengakibatkan pasien menjadi sesak (sulit bernafas). Hal tersebut akan menyebabkan peningkatan angka kematian akibat virus ini. World Health Organization (WHO) telah menetapkan COVID-19 sebagai 
pandemi global pada Rabu, 11 Maret 2020. Penetapan tersebut didasarkan pada sebaran 118 ribu kasus yang terjangkiti di 114 negara. Kasus pertama positif COVID-19 di Indonesia pada Senin, 2 Maret 2019 yang ditularkan melalui transmisi dari manusia ke manusia (Gugus-COVID-19, 2019). Di pertengahan tahun 2020, pemerintah Indonesia mengumumkan 35.295 kasus konfirmasi COVID-19, 2000 kasus meninggal dan 12.636 kasus sembuh dari 424 kabupaten/kota di seluruh 34 provinsi (Pole et al., 2021; WHO, 2020a). Di Nusa Tenggara Timur, jumlah kasus terkonfirmasi positif per tanggal 25 Januari 2021 sebanyak 4425 kasus dan Kota Kupang sebanyak 2126 kasus COVID-19.

Dampak COVID-19 telah menyebabkan keadaan darurat kesehatan masyarakat, ribuan kematian, perekonomian lesu, pengangguran bertambah, dan karantina di seluruh dunia (Aragona et al., 2020). Jumlah kasus penyakit COVID-19 yang tinggi menimbulkan dampak negatif dalam berbagai bidang, terutama ekonomi.

Indonesia mengambil kebijakan pembatasan akses untuk mengantisipasi risiko penularan yang lebih besar lagi dengan menerapkan Pembatasan Sosial Berskala Besar (PSBB) dan larangan penyelenggaraan kegiatan masal (non PSBB). Jenis kegiatan masal yang dimaksud meliputi kegiatan pendidikan dan atau bekerja, kegiatan keagamaan, pernikahan, dan kegiatan-kegiatan sosial lainnya (Gugus-COVID-19, 2019).

Kebijakan terbaru yang disosialisasikan ke masyararakat adalah adaptasi kenormalan baru (WHO, 2020a). Masyarakat dapat kembali beraktivitas dengan tetap memperhatikan dan melindungi diri dengan menerapkan protokol kesehatan. Penularan penyakit infeksi dapat dicegah dengan perilaku yang sederhana seperti mencegah penyebaran droplet ketika bersin atau batuk dengan cara menutup hidung dan mulut atau menggunakan masker. Sebagian besar penyakit pernapasan (ISPA) menular melalui droplet, kontak langsung, khususnya tangan yang terkontaminasi, dan atau melalui aerosol pernapasan infeksius dalam jarak dekat. Penyebab utama penyakit pernapasan (ISPA) sering tidak langsung terdeteksi karena penyakit ini memiliki banyak gejala nonspesifik dan tidak selalu melakukan pemeriksaan diagnosis cepat (WHO, 2020).

Salah satu cara yang ampuh mencegah COVID-19 adalah mencuci tangan sesering mungkin menggunakan sabun dan air mengalir, setidaknya selama 60 detik. Membran lipid virus, kuman, dan bakteri dapat dengan mudah dihancurkan bila mencuci tangan menggunakan sabun (Kemenkes RI, 2020a). Penggunaan cairan pembersih tangan/hand sanitizer diperkenankan dalam situasi tertentu saat sabun dan air bersih tidak tersedia. Kadar alkohol minimal yang direkomendasikan untuk cairan pembersih tangan yang digunakan adalah $60 \%$ agar mendapat hasil yang efektif (Rachmat, 2020).

Badan Pusat Statistik (BPS) menyatakan bahwa belum seluruh masyarakat sadar dalam menerapkan praktik cuci tangan pakai sabun. Hal ini merujuk pada hasil survei kepatuhan masyarakat untuk CTPS hanya 75,38\% dari total 90.967 responden. Lebih jauh dijelaskan oleh BPS, jumlah masyarakat yang menggunakan masker meningkat, tetapi jumlah masyarakat yang mencuci tangan mengalami penurunan, sehingga sangat diperlukan sosialisasi dan edukasi yang terus menerus agar masyarakat menerapkan seluruh protokol kesehatan 3M (memakai masker, menjaga jarak, dan mencuci tangan) dimanapun berada (Tim BPS Covid-19 Statistical Task Force, 2020).

Masalah yang seringkali dijumpai di masyarakat adalah kurangnya kesadaran untuk berperilaku sehat seperti beretika dalam bersin dan batuk, rajin mencuci tangan menggunakan sabun dan air mengalir, serta mengelola stress dengan baik dalam praktik 
kehidupan sehari-hari. Keadaan inilah yang mendukung mudahnya penularan penyakit infeksi di masyarakat. Penelitian ini bertujuan menggambarkan kepatuhan praktik protokol kesehatan COVID-19 dan sumber informasi tentang pencegahan COVID-19 pada penyintas di Kota Kupang.

\section{METODE PENELITIAN}

Jenis penelitian adalah deskriptif kuantitatif. Lokasi penelitian ini di Kota Kupang dan dilaksanakan pada bulan Februari sampai April 2021. Kota Kupang dipilih sebagai lokasi penelitian karena merupakan pusat pemerintahan, sebagai ibukota provinsi, dan total kasus mencapai 6531 per tanggal 22 April 2021 (sumber:http://www.covid19.nttprov.go.id/home/data). Responden penelitian adalah penyintas COVID-19 di Kota Kupang sebanyak 25 orang, yang dicuplik dengan teknik purposive sampling. Sampel yang terpilih dalam penelitian ini harus memenuhi kriteria inklusi dan eksklusi. Kriteria inklusi adalah sebagai berikut: 1) berusia 18-60 tahun; 2) berdomisili tetap di Kota Kupang dalam satu tahun terakhir; 3) bersedia berpartisipasi dalam penelitian. Kriteria eksklusi adalah penyintas COVID-19 yang tidak memiliki penyakit penyerta.

Data yang dikumpulkan berupa data primer dan sekunder. Data primer yang dikumpulkan berupa praktik protokol kesehatan COVID-19 yaitu memakai masker, CTPS/ hand sanitizer, menjaga jarak dan menghindari kerumunan, ketersediaan informasi COVID-19 pada penyintas COVID-19 di Kota Kupang. Data sekunder yang dikumpulkan berupa data penyintas COVID-19 yang diperoleh dari RS Penyangga COVID-19 (Klinik Pratama Undana) serta data kasus COVID-19 di Kota Kupang. Teknik pengumpulan data melalui pengisian kuesioner (google form). Data hasil penelitian selanjutnya disajikan dalam bentuk tabel dan narasi.

\section{HASIL PENELITIAN \\ Karakteristik Responden}

Tabel. 1

Distribusi Karakteristik Responden Penelitian

\begin{tabular}{lcc}
\hline \multicolumn{1}{c}{ Karakteristik Responden } & $\mathrm{n}$ & $\%$ \\
\hline Jenis Kelamin & 7 & 28 \\
Laki-laki & 18 & 72 \\
Perempuan & 25 & 100 \\
\hline Total & 24 & 96 \\
\hline Umur & 1 & 4 \\
$<50$ tahun & 25 & 100 \\
$\geq 51$ tahun & & 20 \\
Total & 5 & 28 \\
\hline Jenis Pekerjaan & 7 & 4 \\
Pelajar/Mahasiswa & 1 & 28 \\
Karyawan swasta/honorer & 7 & 4 \\
TNI/Polri & 1 & 12 \\
PNS (pegawai pemda/pusat/BUMN) & 3 & 4 \\
Freelance & 1 & 100 \\
Guru/Dosen & 25 & \\
Tenaga kesehatan (dokter/bidan/perawat) & & \\
\hline Total &
\end{tabular}


Berdasarkan tabel 1 menunjukkan bahwa responden yang berjenis kelamin perempuan lebih banyak dibandingkan dengan laki-laki (72\%), mayoritas responden berumur kurang dari 50 tahun (96\%), dan paling banyak berprofesi sebagai karyawan swasta/honorer (28\%), PNS (28\%), dan pelajar/mahasiswa (20\%).

\section{Kepatuhan Protokol Kesehatan COVID-19}

Tabel. 2

Distribusi Kepatuhan Protokol Kesehatan COVID-19

\begin{tabular}{lcc}
\hline \multicolumn{1}{c}{ Kepatuhan Prokes COVID-19 } & Patuh & Tidak Patuh \\
\hline Masker & $24(96 \%)$ & $1(4 \%)$ \\
CTPS/ Hand sanitazer & $21(84 \%)$ & $4(16 \%)$ \\
Jaga Jarak & $22(88 \%)$ & $3(12 \%)$ \\
Hindari Kerumunan & $22(88 \%)$ & $3(12 \%)$ \\
\hline
\end{tabular}

Tabel 2 menunjukkan bahwa mayoritas responden patuh dalam menerapkan protokol kesehatan $(>80 \%)$ dan paling banyak dalam praktik penggunaan masker $(94 \%)$.

\section{Ketersediaan Informasi}

Hasil penelitian menunjukkan bahwa sebanyak 9 orang responden memperoleh informasi tentang COVID-19 dari internet atau sosial media (Whatsapp/Facebook/ Instagram/Youtube) dan website resmi WHO dan Kemenkes, 13 orang responden mendapat informasi tersebut dari televisi, internet/sosial media (Whatsapp/Facebook/ Instagram/Youtube), website resmi WHO dan Kemenkes, serta 3 orang mendapatkan informasi tentang COVID-19 ini dari radio, televisi, koran, internet/sosial media (Whatsapp/Facebook/Instagram/Youtube), serta pengumuman dari mobil keliling puskesmas/dinas kesehatan/pemerintah. Berdasarkan hasil ini maka dapat disimpulkan informasi tentang COVID-19 lebih banyak diperoleh responden dari internet/sosial media, media komunikasi massa berupa radio, televisi, dan koran, serta pengumuman dari mobil keliling.

\section{PEMBAHASAN}

Pandemi sudah berjalan lebih dari dua tahun sejak mulai masuk ke Indonesia di tahun 2019 dan virus corona masih terus menyerang penduduk dunia tanpa henti. Indonesia sempat menjadi zona hitam disebagian besar wilayahnya karena angka kasus positif virus corona sudah melebihi 1,5 juta jiwa (02/07/2021). Dengan usaha dan kerja keras dari semua pihak, angka kesembuhan dari COVID-19 mencapai lebih dari 1,3 juta orang (Makarim, 2021).

Hasil penelitian menunjukkan penyintas COVID-19 yang menjadi responden penelitian ini lebih banyak berjenis kelamin perempuan (72\%). Hal ini dapat terjadi karena jumlah penduduk di Kota Kupang lebih banyak berjenis kelamin perempuan. Selain itu, diduga perempuan lebih banyak beraktivitas di luar rumah yang memungkinkan lebih mudah terpapar COVID-19, misalnya ke pasar atau pusat perbelanjaan lainnya dan ke tempat kerja. Mayoritas responden berumur kurang dari 50 tahun $(96 \%)$, dan hal ini berarti responden lebih banyak berada pada rentang usia produktif untuk bekerja maupun belajar. Hal ini didukung oleh hasil penelitian ini yang 
menunjukkan responden paling banyak berprofesi sebagai karyawan swasta/honorer (28\%), PNS (28\%), dan pelajar/mahasiswa (20\%).

Menghindari dan mengurangi penyebaran, penularan COVID-19 membutuhkan usaha yang serius dari semua pihak. Di Indonesia, pemerintah membuat pedoman dan protokol kesehatan untuk menghadapi ancaman virus corona. Protokol kesehatan ini disebut 5M, yaitu 1) menggunakan masker, 2) selalu mencuci tangan dengan sabun dan air mengalir atau menggunakan hand sanitizer saat tidak tersedia air, 3) menjaga jarak, 4) menghindari kerumunan, dan 5) mengurangi mobilitas. Saat ini, upaya $5 \mathrm{M}$ perlu didukung juga dengan menjaga imunitas tubuh dengan membiasakan berperilaku hidup bersih dan sehat, serta melakukan vaksinasi (Makarim, 2021).

Hasil penelitian ini menunjukkan bahwa penggunaan masker merupakan praktik protokol kesehatan yang paling banyak dilakukan oleh responden (96\%). Memakai masker terbukti efektif dalam mencegah penularan virus corona. Penyebaran lewat transmisi udara baik karena batuk atau terlemparnya air liur/droplet dapat dicegah efektif dengan penggunaan masker yang baik. Seperti yang diarahkan oleh Kementerian Kesehatan, masker yang digunakan wajib menutupi hidung dan mulut hingga ujung dagu dengan baik dan saat berada dikerumunan orang yang tidak bisa dihindari, sebaiknya memakai lapis masker.

Sebuah tim peneliti Amerika Serikat melakukan perbandingan tren tingkat infeksi COVID-19 sebelum dan sesudah aturan penggunaan masker wajah diwajibkan di Italia dan New York. Hasil penelitian yang diterbitkan di Prosiding National Academy of Sciences menyebutkan, kedua lokasi mulai menunjukkan tingkat infeksi merata setelah kewajiban penggunaan masker wajah diberlakukan. Fakta yang ditemukan adalah dengan memakai masker sebanyak lebih dari 78.000 infeksi di Italia dapat dicegah selama 6 April dan 9 Mei, dan lebih dari 66.000 infeksi dapat dicegah di New York City selama 17 April dan 9 Mei. Hal lain yang ditemukan dalam penelitian ini adalah penyebaran virus corona di antara anggota keluarga dapat dihentikan dengan menggunakan masker wajah di rumah (WHO, 2020). Praktik menggunakan masker wajah di tempat umum mudah dilakukan dan terbukti paling efektif untuk mencegah penularan antar manusia. Jika praktik ini dilakukan bersama upaya lainnya seperti pembatasan sosial, karantina, dan pelacakan kontak secara simultan, dapat membantu menghentikan penyebaran COVID-19.

Penelitian Atmojo et al., (2020) menyatakan bahwa penggunaan masker efektif untuk mengurangi dan menghindari penularan COVID-19. Masker N95 dan masker bedah memiliki efektivitas di atas 90\%. Bila menggunakan masker kain maka dianjurkan yang memiliki tiga lapisan. Lapisan dalam sebaiknya dari bahan penyerap seperti kapas, lapisan tengah dari bahan bukan tenunan seperti polypropylene, dan lapisan luar dari bahan non-penyerap, seperti campuran poliester atau polyester. Pengawasan orang tua diperlukan untuk bagi penggunaan masker pada anak-anak, untuk memastikan keamanan dan kenyamanan anak dalam bernafas.

Hasil penelitian ini menunjukkan 25 orang responden penyintas COVID-19, terdapat 1 orang saja yang tidak patuh menggunakan masker, bahkan sebelum menderita COVID-19 pun tidak suka menggunakan masker karena merasa pengap. Mayoritas responden (24 orang lainnya) selalu menggunakan masker, tetapi sebagian besar dari jumlah tersebut masih sering membuka masker dengan alasan panas dan pengap. Kemungkinan penularan terjadi juga karena sering tidak disiplin menggunakan masker di tengah kerumunan orang banyak. Ukuran masker dan bahan maskerpun menjadi pertimbangan kemungkinan terjadinya potensi tersebut. Jenis bahan scuba dan jarang 
diganti juga memberi pengaruh terhadap proses penularan. Kadang masker medis yang dipakai digunakan secara berulang dan ini terlihat dari warnanya yang sudah kecoklatan dan lusuh. Lebih lanjut dijelaskan bahwa penggunaan masker kain satu lapis seperti scuba dan buff sangat tidak dianjurkan sehingga diperlukan informasi yang tepat mengenai pemanfaatan masker kain (Atmojo et al., 2020).

Penelitian ini juga sejalan dengan Monitoring Kepatuhan Protokol Kesehatan Tingkat Nasional tahun 2021 yang dirilis oleh Satgas Penanganan COVID-19 Nasional mencatat bahwa Provinsi Nusa Tenggara Timur secara keseluruhan mempunyai kurang lebih $90 \%$ kepatuhan menggunakan masker. BPS tahun 2020 juga merilis hasil survei untuk kepatuhan menggunakan masker mencapai 91,98\% (Tim BPS Covid-19 Statistical Task Force, 2020).

Pemerintah mengusahakan perlindungan yang maksimal bagi masyarakat melalui Surat Edaran Kementerian Kesehatan dengan Nomor: HK.02.02/I/385/2020 ke semua Dinas Kesehatan Provinsi dan Kabupaten untuk secara aktif mencegah penularan COVID-19 melalui gerakan "Semua Pakai Masker" dan penyediaan sarana cuci tangan dengan sabun (CTPS). Pemerintah daerah provinsi dan kabupaten dihimbau untuk melakukan sosialisasi, advokasi dan monitoring penerapan protokol kesehatan di masyarakat (Kemenkes RI, 2020b).

Salah satu cara yang ampuh mencegah COVID-19 adalah mencuci tangan sesering mungkin menggunakan sabun dan air mengalir, setidaknya selama 60 detik. Membran lipid virus, kuman, dan bakteri dapat dengan mudah dihancurkan bila mencuci tangan menggunakan sabun (Kemenkes RI, 2020a). Penggunaan cairan pembersih tangan/hand sanitizer diperkenankan dalam situasi tertentu saat sabun dan air bersih tidak tersedia. Kadar alkohol minimal yang direkomendasikan untuk cairan pembersih tangan yang digunakan adalah $60 \%$ agar mendapat hasil yang efektif (Rachmat, 2020). Cairan pembersih/hand sanitizer ini juga dapat dibuat sendiri dengan mengikuti standar dan panduan dari WHO. Namun tetap perilaku mencuci tangan pakai sabun dan air mengalir lebih dianjurkan daripada menggunakan cairan pembersih tangan berbasis alkohol. Semua jenis kuman dari tangan dapat dihilangkan menggunakan sabun dan air bersih, sedangkan hand sanitizer hanya mengurangi jumlah kuman tertentu di kulit dan hanya dapat digunakan bila tangan tidak kotor dan berminyak. Jenis kuman norovirus, cryptosporidium, dan clostridioides difficile, serta bahan kimia berbahaya seperti pestisida dan logam berat juga tidak dapat dihilangkan menggunakan hand sanitizer (Rachmat, 2020).

Badan Pusat Statistik (BPS) menyatakan bahwa belum seluruh masyarakat sadar dalam menerapkan praktik cuci tangan pakai sabun. Hal ini merujuk pada hasil survei kepatuhan masyarakat untuk CTPS hanya 75,38\% dari total 90.967 responden. Lebih jauh dijelaskan oleh BPS, jumlah masyarakat yang menggunakan masker meningkat, tetapi jumlah masyarakat yang mencuci tangan mengalami penurunan, sehingga sangat diperlukan sosialisasi dan edukasi yang terus menerus agar masyarakat menerapkan seluruh protokol kesehatan 3M (memakai masker, menjaga jarak, dan mencuci tangan) dimanapun berada (Tim BPS Covid-19 Statistical Task Force, 2020).

Hasil penelitian mencatat bahwa 21 orang atau 84\% responden mempunyai perilaku CTPS atau selalu menggunakan hand sanitizer. Responden berpendapat bahwa perilaku tersebut harus dilakukan karena sangat mempengaruhi kesehatan pribadi yaitu terhindar dari penularan penyakit, bahkan beberapa dari responden sampai merasakan tidak nyaman jika tidak melakukan CTPS setiap beberapa saat. Responden juga menggunakan hand sanitizer, khususnya ketika berada di luar rumah dan tidak tersedia 
sarana CTPS di tempat tujuan. Bila dilihat dari karakteristik responden, perilaku tersebut bisa terjadi karena memang latar belakang pendidikan dan pekerjaan berpengaruh terhadap pengetahuan dan praktik yang dilakukan. Sebagian besar responden termasuk kategori berpendidikan tinggi dan berprofesi sebagai Pegawai Negeri Sipil/TNI-Polri dan karyawan swasta/honorer, serta selebihnya adalah dosen/guru dan tenaga kesehatan.

Hasil penelitian Zuhroidah et al., (2021) pada masyarakat yang berkunjung ke Puskesmas Pasuruan mempertegas pendapat Notoatmodjo dengan hasil penelitiannya. Tingkat pengetahuan memiliki hubungan yang signifikan dengan kepatuhan cuci tangan pakai sabun. Pengetahuan berperan penting dalam menentukan perilaku masyarakat.

Kesadaran menjaga jarak secara fisik antarmanusia menjadi sangat penting karena virus berada pada media udara yang selalu bergerak, sehingga penularannya terjadi sangat cepat melalui hidung dan mulut. World Health Organization (WHO) menghimbau untuk melakukan physical distancing dengan tujuan agar mata rantai penularan virus corona dapat terputus karena virus ini hanya bisa hidup dalam tubuh manusia sebagai inang (host). Tujuan lainnya adalah mencegah terjadinya kematian masal karena COVID-19 bisa berakibat fatal pada usia produktif. Namun, banyak orang tidak memperhatikan himbauan physical distancing bahkan masih beraktivitas secara normal. Satu orang terinfeksi yang tidak melakukan jaga jarak bisa menyebabkan 406 orang lainnya tertular pada hari ke-30. Jika kontak sosial dikurangi sebesar 50\%, maka jumlah penderita menjadi 15 orang, bahkan jika dikurangi sampai $75 \%$, maka laju penyebaran virus corona dapat ditekan lagi menjadi 2,5 orang pada periode waktu yang sama (30 hari) (WHO, 2020).

Survei BPS tentang praktik menjaga jarak selama seminggu terakhir secara online pada 7-14 September 2020 melibatkan 90.967 responden yang terdiri dari 44,77\% laki-laki dan 55,23\% perempuan. Hasil survey mencatat kepatuhan masyarakat untuk selalu menjaga jarak sebesar 73,54\% (Tim BPS Covid-19 Statistical Task Force, 2020). Hasil penelitian ini menunjukkan mayoritas responden patuh terhadap anjuran dan himbauan menjaga jarak (88\%) dan hasil ini sejalan dengan hasil survei BPS tersebut.

Bila ditinjau dari karakteristik responden yang patuh tersebut, sebagian besar responden berpendidikan tinggi (tamat Diploma/Strata I/Strata II/Strata III), serta berprofesi sebagai Pegawai Negeri Sipil/TNI-Polri dan karyawan swasta. Umurpun berada pada masa dewasa dan produktif yang sangat paham dan mengerti pentingnya menjaga protokol kesehatan sehingga terhindar dari penularan virus corona saat masa pandemi ini. Apabila tertular, diwajibkan beristirahat dan melakukan isolasi di rumah sakit maupun isolasi mandiri di rumah. Pada saat mengalami sakit COVID-19, tercatat 22 orang melakukan isolasi mandiri, dan hanya 3 orang yang diisolasi di rumah sakit selama kurang lebih 14-20 hari. Keadaan ini berpengaruh terhadap produktivitas kerja yang berdampak pada penghasilan terutama bagi karyawan swasta/ honorer.

Arief \& Juni (2020) membuat kesimpulan sebagai hasil penelitiannya yaitu perubahan perilaku masyarakat yang diakibatkan oleh penerapan kebijakan physical distancing dan social distancing merupakan cara terbaik guna menghambat penyebaran dan penularan COVID-19. Kebijakan pemerintah saat melaksanakan kebijakan physical distancing dan social distancing dengan menerapkan protokol kesehatan diberlakukan melalui sosialisasi mengenai penerapan pola hidup sehat. Beberapa contoh praktik physical distancing yang dilakukan masyarakat sehari-hari misalnya tidak keluar rumah kecuali untuk kondisi yang sangat darurat seperti membeli kebutuhan pokok atau 
berobat, menyapa orang lain tanpa berjabat tangan, berolahraga secara rutin di rumah minimal 30 menit sehari untuk menjaga daya tahan tubuh, serta memanfaatkan fasilitas gadget yang dimiliki agar tetap dapat bekerja atau belajar dari rumah. Hal ini sangat berdampak positif bagi kesehatan masyarakat.

Demikian juga pada praktik menghindari kerumunan, survei BPS mencatat bahwa kepatuhan masyarakat menghindari jabat tangan sebesar $81,85 \%$, menjauhi kerumunan 76,69\%, dan mengatur jarak fisik 73,54\% (Tim BPS Covid-19 Statistical Task Force, 2020). Hasil yang sama juga terdapat pada penelitian ini, dimana dari 25 orang responden, 22 orang $(88 \%)$ yang patuh melakukan praktik menghindari kerumunan. Kepatuhan responden didasarkan oleh pemahaman dan pengertian para responden, bahwa virus corona yang menyebabkan COVID-19 perlu dihindari. Responden sadar bahwa salah satu cara menghindari penularan adalah selalu menghindari kerumunan. Pekerjaan dapat dilakukan dari rumah yang didukung dengan penerapan work from home oleh tempat kerja dan pemerintah. Responden menjelaskan bahwa walaupun WFH tetapi tertular juga karena saat itu kondisi imun menurun, dan ada virus di sekitar responden yang dibawa oleh Orang Tanpa Gejala (OTG).

Perkembangan informatika sangat pesat dalam setiap sudut kehidupan masyarakat. Didukung oleh umur, pendidikan, dan pekerjaan responden yang sudah mapan, maka bisa dipastikan bahwa hampir sebagian besar kehidupannya tidak terlepas dari pengaruh media massa. Apalagi disaat semua orang diharuskan tetap tinggal di rumah dan mengurangi aktivitasnya di luar rumah, maka salah satu kesibukan yang dilakukan adalah mengakses media massa, baik itu televisi, internet/sosial media (Whatsapp/Facebook/Instagram/Youtube), ataupun mendengarkan radio.

Hasil penelitian ini sejalan dengan penelitian Rizqah et al., (2021) yang menyatakan bahwa terdapat hubungan pengetahuan dengan kepatuhan penggunaan masker sebagai upaya pemutus mata rantai penularan COVID-19 di Kelurahan Bontoa Maros. Lebih lanjut dijelaskan bahwa dengan tingkat pengetahuan yang baik akan mendukung seseorang untuk selalu patuh menggunakan masker guna perlindungan diri dari bahaya penularan COVID-19, walaupun diantara responden yang patuh dalam menggunakan masker memiliki pengetahuan yang kurang. Sebagian dari responden yang tidak patuh dikarenakan kurangnya pemahaman tentang COVID-19. Selain itu, responden berpendapat bahwa memakai masker menimbulkan rasa tidak nyaman, merasa sesak, dan merasa lingkungannya aman dari COVID-19 sehingga tidak perlu menggunakan masker.

Oleh karena itu, idealnya masyarakat lebih bijaksana dalam memilih jenis informasi yang baik dan tepat untuk ditonton atau didengar, termasuk informasi mengenai penyakit COVID-19. Ketakutan, kepanikan dan kewaspadaan yang timbul pada setiap individu memberikan respon yang positif untuk mencari informasi guna menghindari penularannya, terutama disaat masa new normal life. Masyarakat harus bisa beradaptasi dengan kondisi ini untuk tetap mewujudkan pembangunan yang berkelanjutan bagi kesejahteraan seluruh umat manusia, dengan kembali produktif di masa pandemi COVID-19 dan berusaha beradaptasi dengan lingkungan sekitarnya dengan tetap disiplin mererapkan protokol kesehatan.

\section{SIMPULAN}

Mayoritas penyintas COVID-19 patuh dalam menggunakan alat pelindung diri berupa masker, melakukan cuci tangan pakai sabun/hand sanitizer, menerapkan jaga jarak, dan menghindari kerumunan. Sumber informasi tentang pencegahan COVID-19 pada 
penyintas COVID-19 di Kota Kupang berasal dari televisi, radio, dan internet/sosial media (Whatsapp/Facebook/Instagram/Youtube). Paparan informasi mengenai cara pencegahan dan pengalaman mengalami COVID-19 menjadikan penyintas COVID-19 menjadi lebih patuh dalam menerapkan praktik protokol kesehatan di masyarakat.

\section{SARAN}

Diperlukan motivasi dan perilaku disiplin mematuhi protokol kesehatan serta bijaksana mencari informasi mengenai penyakit dan penularan COVID-19 agar terhindar dari bahaya penularan di masa new normal life dan tetap produktif.

\section{DAFTAR PUSTAKA}

Aragona, M., Barbato, A., Cavani, A., Costanzo, G., \& Mirisola, C. (2020). Negative Impacts of COVID-19 Lockdown on Mental Health Service Access and Followup Adherence for Immigrants and Individuals in Socio-Economic Difficulties. Public Health, 186, 52-56. https://doi.org/10.1016/j.puhe.2020.06.055

Arief, K., \& Juni, A. (2020). Pengaruh Physical Distancing dan Social Distancing terhadap Kesehatan dalam Pendekatan Linguistik. Jurnal Syntax Transformation, $1(4)$, 14-19. http://jurnal.syntaxtransformation.co.id/index.php/jst/article/view/42/58

Atmojo, J. T., Iswahyuni, S., Rejo, R., Setyorini, C., Puspitasary, K., Ernawati, H., Syujak, A. R., Nugroho, P., Putra, N. S., Nurrochim, N., Wahyudi, W., Setyawan, N., Susanti, R. F., Suwarto, S., Haidar, M., Wahyudi, W., Iswahyudi, A., Tofan, M., Bintoro, W. A., \& Mubarok, A. S. (2020). Penggunaan Masker dalam Pencegahan dan Penanganan Covid-19: Rasionalitas, Efektivitas, dan Isu Terkini. Avicenna: Journal of Health Research, 3(2), 84-95. https://doi.org/10.36419/avicenna.v3i2.420

Gugus-COVID-19, T. (2019). Penanganan Pandemi COVID-19. 19. https://covid19.go.id/storage/app/media/Protokol/2020/Mei/Protokol Percepatan Penanganan Pandemi Corona Virus Disease 2019.pdf

Kemenkes RI. (2020a). Panduan Cuci Tangan Pakai Sabun. Kesehatan Lingkungan, 20. https://kesmas.kemkes.go.id

Kemenkes RI. (2020b). SE Kemenkes No. HK.02.02-I-385-2020 tentang Penggunaan Masker dan Penyediaan Sarana CTPS.pdf

Makarim, F. R. (2021). Mengenal Protokol Kesehatan 5M untuk Cegah COVID-19. Halodoc. https://www.halodoc.com/artikel/mengenal-protokol-kesehatan-5muntuk-cegah-covid-19

Pole, J., Andri, J., \& Padila, P. (2021). Cardiovascular Patient's Anxiety in the Time of the Covid-19 Pandemic. JOSING: Journal of Nursing and Health, 2(1), 15-21. https://doi.org/https://doi.org/10.31539/josing.v2i1.3022

Rachmat, B. (2020). Apa yang Harus Ketahui Terkait Hand Sanitizers! Puslitbang Upaya Kesmas Kementerian Kesehatan RI. http://www.pusat3.litbang.kemkes.go.id/news-349-apa-yang-harus--ketahuiterkait-hand-sanitizers-.html

Rizqah, S. F., Amelia, R. A., \& Haeruddin, H. (2021). Hubungan Perilaku Masyarakat dengan Kepatuhan Penggunaan Masker untuk Memutus Rantai Penularan Covid19 di Kelurahan Bontoa Maros. Journal of Muslim Community Health, 2(3), 165175. http://pasca-umi.ac.id/index.php/jmch/article/view/553 
Tim BPS Covid-19 Statistical Task Force. (2020). Hasil Survei Perilaku Masyarakat di Masa Pandemi Covid-19 (7-14 September 2020). In Perilaku Masyarakat di Masa Pandemi Covid-19 BPS RI (Vol. 19, Issue September). https://www.bps.go.id/publication/2020/09/28/f376dc33cfcdeec4a514f09c/perilak u-masyarakat-di-masa-pandemi-covid-19.html

WHO. (2020a). Coronavirus Disease Coronavirus Disease Situation World Health World Health Organization Organization. 19, 1-12. https://www.who.int/docs/default-source/searo/indonesia/covid19/externalsituation-report-33-11-november-2020.pdf?sfvrsn=f338094a_2

WHO. (2020b). Modes of Transmission of Virus Causing COVID-19: Implications for IPC Precaution Recommendations. Geneva: World Health Organization;, Available, 1-10. https://www.who.int/publications-detail/modes-of-transmissionof-virus-causing-covid-19-implications-for-ipc-precaution-recommendations

Zuhroidah, I., Toha, M., \& Sujarwadi, M. (2021). Pengetahuan tentang Penularan COVID-19 dan Kepatuhan Cuci Tangan Pakai Sabun. Jurnal Keperawatan, 13(1), 213-226. https://journal.stikeskendal.ac.id/index.php/Keperawatan/article/view/ 1498 